\title{
Potential Applications of a Novel Ballast Water Pretreatment Device: Grinding Device
}

\author{
Bonggil Hyun ${ }^{1}$, Hyung-Gon Cha ${ }^{1}$, Yeong-Kyu An ${ }^{2}$, Yong-Seok Park ${ }^{3}$, Min-Chul Jang ${ }^{1}$, Pung-Guk Jang ${ }^{1}(\mathbb{C}$ \\ and Kyoungsoon Shin ${ }^{1, *}$ \\ 1 Ballast Water Research Center, Korea Institute of Ocean Science and Technology, Geoje 53201, Korea; \\ bghyun@kiost.ac.kr (B.H.); Chahg@kiost.ac.kr (H.-G.C.); mcjang@kiost.ac.kr (M.-C.J.); \\ pgjang@kiost.ac.kr (P.-G.J.) \\ 2 Busan Techno-Park, Busan 46239, Korea; ayk0437@btp.or.kr \\ 3 Waterfin Inc., Seoul 08512, Korea; andy@waterfin.com \\ * Correspondence: ksshin@kiost.ac.kr
}

check for updates

Citation: Hyun, B.; Cha, H.-G.; An, Y.-K.; Park, Y.-S.; Jang, M.-C.; Jang, P.-G.; Shin, K. Potential Applications of a Novel Ballast Water Pretreatment Device: Grinding Device. J. Mar. Sci. Eng. 2021, 9, 1213. https://doi.org/ $10.3390 /$ jmse9111213

Academic Editor: Md Jahir Rizvi

Received: 24 September 2021

Accepted: 29 October 2021

Published: 2 November 2021

Publisher's Note: MDPI stays neutral with regard to jurisdictional claims in published maps and institutional affiliations.

Copyright: (c) 2021 by the authors. Licensee MDPI, Basel, Switzerland. This article is an open access article distributed under the terms and conditions of the Creative Commons Attribution (CC BY) license (https:// creativecommons.org/licenses/by/ $4.0 /)$.

\begin{abstract}
To investigate the removal efficiency of the grinding device (GD) as a potential replacement for the pretreatment filtration device of ballast water, solid grinding and viability experiment were conducted according to a treatment flow rate of 5 tons (Pilot test, PT), and 200 tons (Full-scale test, FST) per $h$. The solid grinding effect was observed in the particle size of $\geq 25 \mu \mathrm{m}$. Under the high-turbidity conditions ( $\left.>300 \mathrm{mg} \mathrm{L}^{-1}\right)$, no change in pressure $\left(0.98 \mathrm{kgf} / \mathrm{cm}^{2}\right)$ or stoppage in the GD were observed. The removal efficiency of the GD for $>100 \mu \mathrm{m}$ organism was determined to be $100 \%$ in both PT and FST, whereas the removal efficiency was determined to be $93 \%$ and $87 \%$ in the PT and FST, respectively, for the $<100 \mu \mathrm{m}$ organism. There was no statistically significant change in the removal efficiency stored within $2 \mathrm{~h}$ after passing through the GD, while the removal efficiency was determined to be $\geq 99 \%$ in the sample stored for $120 \mathrm{~h}$. Future study is necessary to determine the additional removal efficiency according to the storage period after passing through the GD, but the GD might be utilized as the pretreatment device for the ballast water management system.
\end{abstract}

Keywords: grinding device; ballast water; pretreatment filtration device; high-turbidity condition; ballast water management system

\section{Introduction}

The annual amount of ballast water that is used for the safe operation of vessels reaches approximately 3.5 gigatons and is discharged into the world's oceans [1-3]. Various marine organisms, such as bacteria, microorganisms, and invertebrates are present in the ballast water. The presence of invasive alien species or toxic alien organisms could seriously affect the marine ecosystem, human health, and fishery economies around the ports where the ballast water is discharged [4-7]. Thus, to prevent disturbance of the marine ecosystem by ballast water, the International Maritime Organization (IMO) adopted the "International Convention for the Control and Management of Ships' Ballast Water and Sediments" in February 2004 [8]. The Ballast Water Management Convention classifies organisms in ballast water into three size groups ( $\geq 50 \mu \mathrm{m}, \geq 10$ and $<50 \mu \mathrm{m}$, and $<10 \mu \mathrm{m})$ and presents a discharge standard regulation for each size group. For example, for the $\geq 50 \mu \mathrm{m}$ organisms, the number of viable organisms in the discharge water must be $<10$ individuals per $\mathrm{m}^{3}$. The Ballast Water Management Convention came into effect on 8 September 2017, and all vessels navigating worldwide must install a ballast water management system (BWMS) in accordance with the D-1(Ballast Water Exchange Standard) [9] or D-2 (Ballast Water Performance Standard) [10] standards by 8 September 2024.

Typically, the BWMS is involved in two processes: a major process that dies organisms through electrolysis, chemical injection (including $\mathrm{NaDCC}, \mathrm{NaOCl}$, and $\left.\mathrm{ClO}_{2}\right)$, ozone $\left(\mathrm{O}_{3}\right)$ and UV treatment, and a pretreatment filtration, located at the front end of the major 
process, that increases the treatment efficiency by removing large size organisms. As of 2019,46 out of 66 BWMSs that have received basic and final approval and utilize a filtration device as a pretreatment device account for approximately 70\% of the entire BWMSs [11]. Most of the filters used in the filtration process use an element, such as a wedge wire or mesh with 40-50 $\mu \mathrm{m}$, inevitably resulting in clogging in coastal areas with a high turbidity and high density of marine organisms, and as a result, interrupting normal BWMS operation. Jang et al. [11] reported that filter clogging frequently occurs when operating the BWMS in coastal areas, such as the Port of Shanghai, China where a significantly high total suspended solids (TSS) concentration is maintained, and captains operating a vessel equipped with a filter as pretreatment device are reluctant to operate the BWMS in coastal areas with a high turbidity. Briski et al. [12] also reported that filter clogging occurred by organisms with soft bodies (e.g., Holopedium gibberum) and that the BWMS operation time increased by $30 \%$ compared to the control group in which the filter was not clogged. Filter clogging in this pretreatment filtration causes maintenance expenses for continuous filter cleaning and replacement and has a serious impact on the safe operation of vessels in specific coastal areas where the BWMS is not operational [13]. Moreover, because the load of the pretreatment device also affects the treatment efficiency of the main treatment device, stable operation of the pretreatment device under various environmental conditions is essential [14].

A grinding device (GD) is composed of a fixed unit with grooves and a drive unit based on a flow-through method, and it crushes marine organisms and solids, which pass through the device while it rotates at a high speed, through impact, shear force, and cavitation (Figure 1). Unlike the conventional screen-type pretreatment filtration device technology for ballast water, the corresponding technology directly decomposes and discharges aquatic organisms, and this technology has a structural feature that does not induce clogging. Therefore, this study examines the applicability of a BWMS as a pretreatment device that can replace the current filtration system by identifying the removal efficiency of this GD regarding the $\geq 50 \mu \mathrm{m}$ size organism as well as its grinding effect on solids. The grinding performance evaluation on solids (5 tons scale) determined the grinding efficiency of the GD by using different dust sizes. Furthermore, a 5 ton-scale pilot test (PT), and 200-tonscale full-scale test (FST) were designed to evaluate the removal efficiency of organisms immediately after treatment, by treatment time, and by time after treatment. Both PT and FST included the analysis of the zooplankton mortality rate according to size.

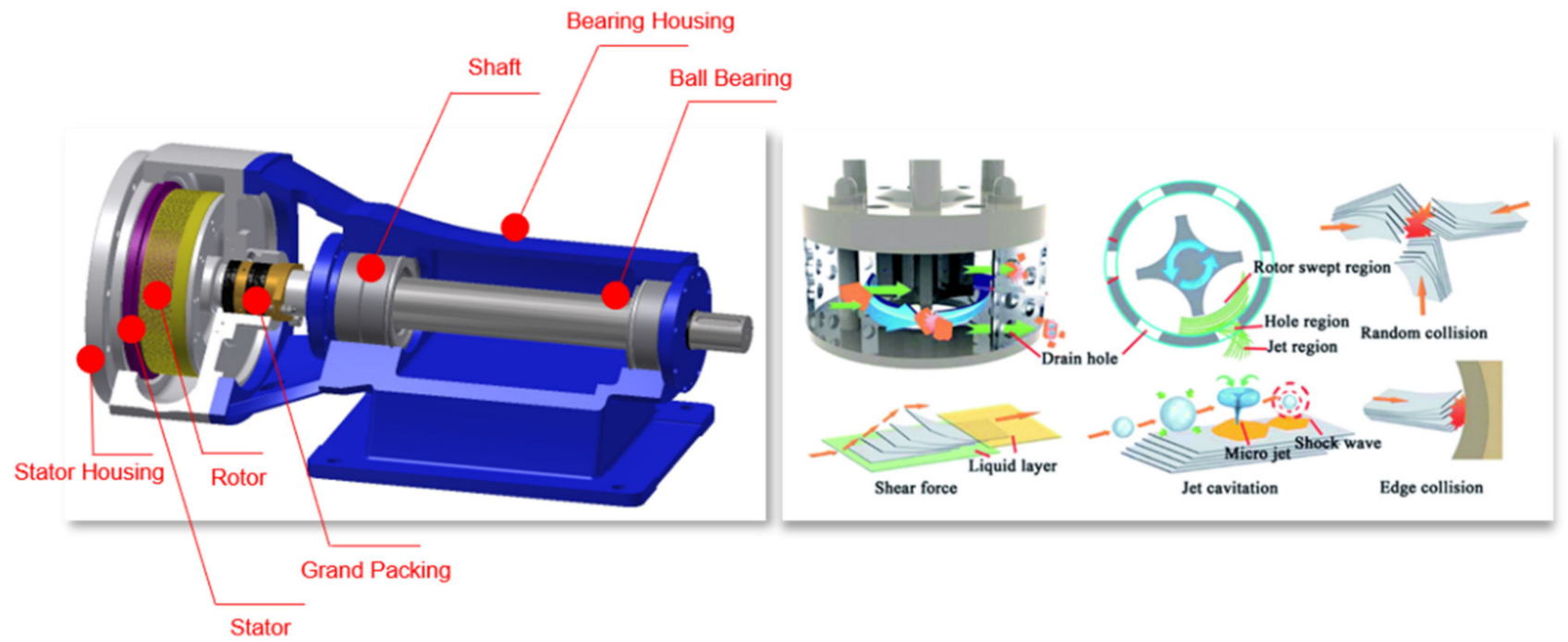

Figure 1. Schematic diagram of the working principle of grinding device. 


\section{Materials and Methods}

\subsection{Principle of GD}

The GD is a device that uses the centrifugal force of the rotor-stator (Figure 1). Rotor-Stator is a set of ring-shaped tools with grooves or holes processed in the direction perpendicular to the axis. During operation, the rotor rotates at a speed of $24 \mathrm{~m} \mathrm{~s}^{-1}$, forming a mesh with the stator. When the seawater to be treated is supplied to the central part of the shaft and passes through the rotor-stator structure with strong centrifugal force, organisms are killed by high-speed physical force and water pressure. It has the following physical effects: (i) Shearing is performed by the edge of the tool in the circular space of the rotor-stator, (ii) organisms die due to the pressure change that occurs when they pass through the rotor-stator at high speed. The specifications of GD that are used in PT and FST are specified in Table 1.

Table 1. Grinding device specification used in pilot test and full-scale test.

\begin{tabular}{lll}
\hline \multicolumn{2}{l}{ Specification of Grinding Device } \\
\hline Test Name & Pilot Test & Full-Scale Test \\
\hline Product Characteristic & & \\
\hline Capacity & $5 \mathrm{~m}^{3} \mathrm{~h}^{-1}$ & $200 \mathrm{~m}^{3} \mathrm{~h}^{-1}$ \\
\hline Design and Operation conditions & & \\
\hline Design pressure & $8 \mathrm{bar}$ & $10 \mathrm{bar}$ \\
Design temperature & $80{ }^{\circ} \mathrm{C}$ & $110{ }^{\circ} \mathrm{C}$ \\
Suction pressure & Min. $0.5 \mathrm{bar}$ & Min. $0.5 \mathrm{bar}$ \\
Operating pressure & $0-4 \mathrm{bar}$ & $0-2 \mathrm{bar}$ \\
Operating speed & Max. $4000 \mathrm{rpm}$ & Max. $1700 \mathrm{rpm}$ \\
\hline Tool and Housing materials & & \\
\hline Tool materials (rotor and stator) & STS316Ti & STS316Ti \\
Housing materials & STS316 & STS316 \\
Stator support materials & STS316 & STS316 \\
\hline
\end{tabular}

\subsection{Evaluation of Solid Grinding Efficiency}

The solid grinding evaluation experiment was conducted three times in total from 17 April 2019 to 18 April 2019 at the pier of the South Sea Research Institute of the Korea Institute of Ocean Science and Technology (SSRI KIOST). The concentration of solids in the experimental water ( $5 \mathrm{~m}^{3}$ of seawater) was prepared by injecting $\geq 2 \mathrm{~kg}$ of ISO 12103-1 Arizona Test dust (Powder Technology Inc., Arden Hills, Minnesota, USA) of two different sizes that are commonly used for filtration testing $[15,16]$. The two types of Arizona Test Dusts are Fine test dust (A2) and A4 Coarse test dust (A4), between which A4 has a relatively larger particle size and wider distribution. Table 2 shows the size and distribution information of each dust provided by the manufacturer. From approximately 30 min before the start of the experiment, approximately 5 tons of experimental water was stirred, and $15 \mathrm{~L}$ of the experimental water from each of the surface, middle, and bottom layers was sampled using a Niskin water sampler before the start of the experiment, and then they were mixed. The flow rate during the experiment that was conducted for approximately $50 \mathrm{~min}$ was approximately $5 \mathrm{~m}^{3} \mathrm{~h}^{-1}$, and the treated water was mixed after sampling with $4 \mathrm{~L}$ every $10 \mathrm{~min}$ (a total of five times). A $20 \mathrm{~L} \mathrm{PE} \mathrm{bottle} \mathrm{(polyethylene} \mathrm{bottle)}$ was used as a sampling container. 
Table 2. Particle size distribution of Arizona test dust.

\begin{tabular}{ccc}
\hline Size $(\mu \mathrm{m})$ & $\begin{array}{c}\text { A2 Dust } \\
\text { (\% Less Than) }\end{array}$ & $\begin{array}{c}\text { A4 Dust } \\
\text { (\% Less Than) }\end{array}$ \\
\hline 0.97 & $4.5-5.5$ & $0.74-0.83$ \\
1.38 & $8.0-9.5$ & $1.8-2.1$ \\
2.75 & $21.3-23.3$ & $5.5-6.3$ \\
5.5 & $39.5-42.5$ & $11.5-12.5$ \\
11 & $57.0-59.5$ & $21.0-23.0$ \\
22 & $73.5-76.0$ & $36.0-38.5$ \\
44 & $89.5-91.5$ & $58.0-60.0$ \\
88 & $97.9-98.9$ & $85.0-86.5$ \\
124.5 & $99.0-100.0$ & $93.0-94.0$ \\
176 & 100 & $97.2-98.2$ \\
248.9 & - & $99.0-100.0$ \\
352 & - & 100 \\
\hline
\end{tabular}

The samples were immediately transferred to the laboratory and analyzed for TSS and grain size analysis. For the TSS analysis, $500 \mathrm{~mL}$ of experimental water and treated water were filtered through GF/F filter paper (Whatman Inc., Maidstone, Kent, UK), which was dried at $110^{\circ} \mathrm{C}$ for $2 \mathrm{~h}$ and weighed. After filtration, the filter paper was further dried at $110{ }^{\circ} \mathrm{C}$ for $2 \mathrm{~h}$ and then weighed [17] (2540 D). The TSS concentration was determined with the weight difference before and after filtration $(n=3)$. To compare the dust particle size $(\mu \mathrm{m})$ before and after grinding treatment, $16 \mathrm{~L}$ each of test water and treated water samples were concentrated $(500 \mathrm{~mL}$ bottle $\times 4$ ) based on the study of Salim and Cooksey [18], and the final volume of the concentrated samples was adjusted to $100 \mathrm{~mL}$. The size and distribution of solid particles in the concentrated sample $(100 \mathrm{~mL})$ were analyzed using Sedigraph 5000D (Micromeritics Inc., Norcross, GA, USA), an X-ray automatic particle size analyzer, and the size of the analyzed particles were sorted as $<25 \mu \mathrm{m}, \geq 25-50 \mu \mathrm{m}$, and $>50 \mu \mathrm{m}$ (A4 experiment alone was conducted) to evaluate the performance of the GD.

\subsection{Removal Efficiency on $\geq 50 \mu \mathrm{m}$ Zooplankton Species}

\subsubsection{Pilot Test}

From 30 October 2018 to 9 November 2018 (a total of eight times), a $5 \mathrm{~m}^{3} \mathrm{~h}^{-1}$ scale PT on the GD was conducted at the pier of the SSRI KIOST (Figure 2). Although it is a PT, zooplankton was concentrated by utilizing a net (mesh size: $45 \mu \mathrm{m}$ ) at the pier and injected into a test water tank $\left(5 \mathrm{~m}^{3}\right)$ to meet the criteria on the number of $\geq 50 \mu \mathrm{m}$ test organisms ( $\geq 100,000$ indiv. $\mathrm{m}^{-3}, \geq 3$ phyla, 5 species) in the IMO G8 guidelines [19]. The experiment was conducted for $50 \mathrm{~min}$ or more, and air was injected through an aerator during the experiment to maintain the test water homogeneously. The homogeneously mixed test water passed through the GD at a flow rate of approximately $5 \mathrm{~m}^{3}$ per $\mathrm{h}$. The test water $(10 \mathrm{~L})$ and treated water (total amount: 4.4-4.8 $\mathrm{m}^{3}$ ) were concentrated (final volume: $1 \mathrm{~L}$ ) using a net (mesh size: $32 \mu \mathrm{m}$ ) to determine the abundance and species composition of viable organisms under a dissecting microscope (SteREO Discovery V12, ZEISS Co., Oberkochen, Germany) [17] (10200 G) [20,21]. The concentrated samples of the test water and treated water were repeatedly observed five times or more by $10 \mathrm{~mL}$. In the eighth experimental session among all experiments, to identify the minimum size of the organisms that can be processed by the GD, the zooplankton removal rate and death pattern according to the size of the organism (based on the shorter side) were analyzed using an image analysis system (Zen software, ZEISS Co., Oberkochen, Germany) mounted on a dissecting microscope. 

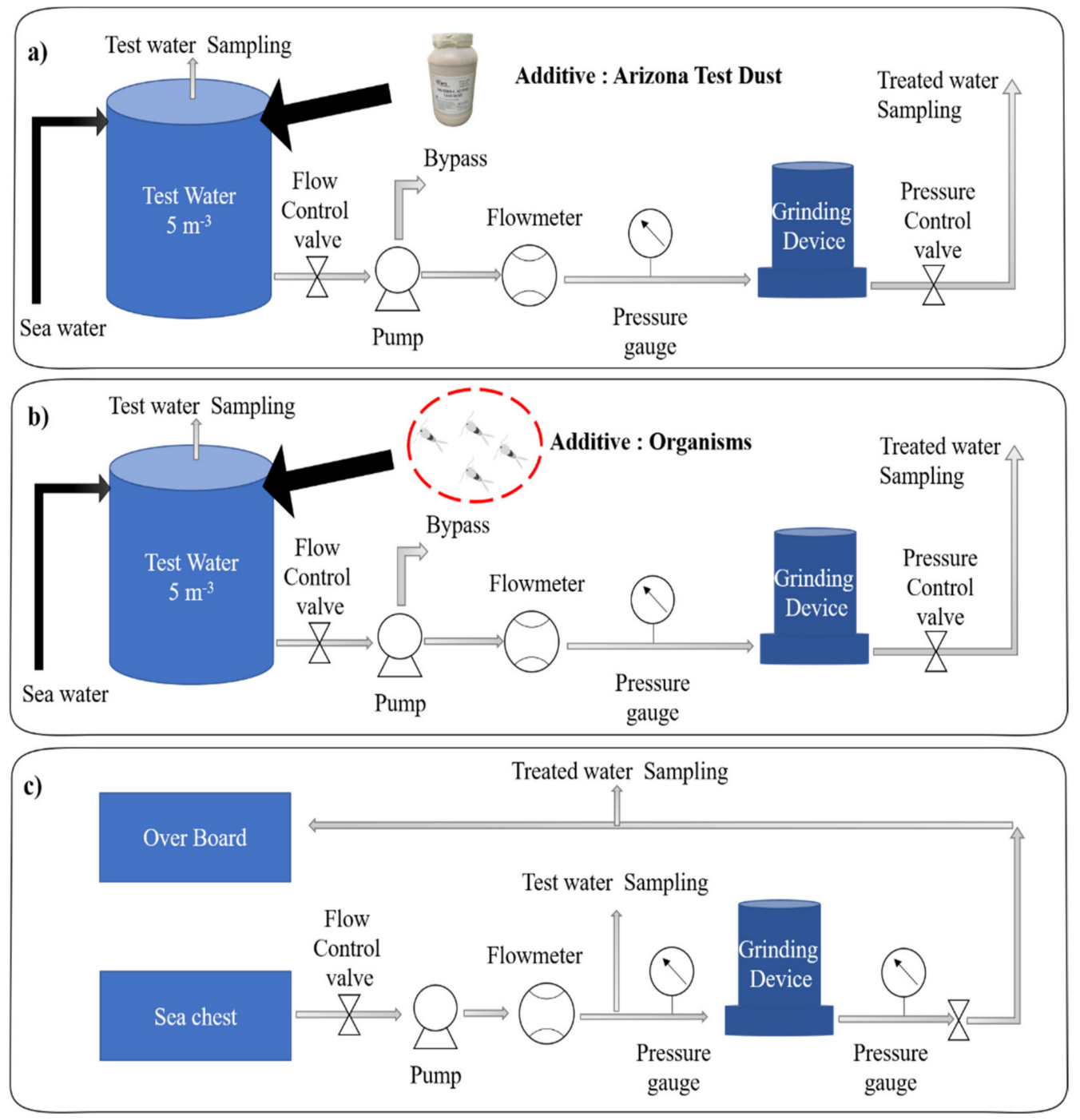

Figure 2. Schematic diagram of (a) evaluation of solid grinding efficiency, (b) pilot test and (c) fullscale test for grinding device.

\subsubsection{Full-Scale Test}

The FST experiment utilizing a GD of a size that is mountable on a vessel was conducted on a barge anchored in Gamcheon Port, Busan, a total of six times from 3 July 2019 to 25 July 2019. All FSTs were conducted by allowing seawater around the barge to pass through the GD at a flow rate of approximately 200 tons per $h$ using a pump. The experiment was conducted for approximately $30 \mathrm{~min}$, and the pressure between the pump and the GD was maintained at approximately $1.5 \mathrm{kgf} \mathrm{cm}^{-2}$ (Table 3). The test water and treated water were continuously sampled during the operation time, and both types of water were respectively injected into 5 ton tanks, and $200 \mathrm{~L}$ of test water and $300 \mathrm{~L}$ of treated water were concentrated (final volume: $0.5-2 \mathrm{~L}$ ) using a net (mesh size: $32 \mu \mathrm{m}$ ) to determine the viability the standard movement/response to stimuli techniques under a dissecting microscope (SteREO Discovery V12, ZEISS Co., Oberkochen, Germany). Ten mL of concentrated samples from the test water and the treated water were repeatedly observed five times or more. To check the mortality rate according to storage time for $\geq 50 \mu \mathrm{m}$ organisms in the treated water, which had passed through the GD, $20 \mathrm{~L}$ of the treated water sample was injected into polycarbonate bottles (PC bottles). These bottles were stored in a dark room (water temperature) to determine the additional removal efficiency of organisms in short-term (fourth and fifth session: $0 \mathrm{~h}, 1 \mathrm{~h}, 2 \mathrm{~h}$ ) and long-term periods (sixth session: $120 \mathrm{~h}$ ). In the first to fifth experiments, the removal efficiency depending on the size and 
species of the organisms was identified, and in the sixth experiment, only the removal efficiency according to time for the total number of surviving individuals was identified.

Table 3. Summary of operation parameter for biological efficiency test.

\begin{tabular}{|c|c|c|c|c|}
\hline Test Type & Test Cycle & $\begin{array}{l}\text { Flow Rate } \\
\left(m^{3} h^{-1}\right)\end{array}$ & $\begin{array}{c}\text { Pressure } \\
(\text { Mean } \pm \mathrm{SD}) \\
\left(\mathrm{kfg} \mathrm{cm}^{-2}\right)\end{array}$ & $\begin{array}{l}\text { Operating Time } \\
\text { (Minute) }\end{array}$ \\
\hline \multirow{2}{*}{ Pilot (grinding test) } & A2 & 4.93 & $0.97(0.04)$ & 57 \\
\hline & A4 & 4.95 & $0.99(0.04)$ & 58 \\
\hline \multirow{8}{*}{ Pilot } & 1 & 5.13 & $1.02(0.08)$ & 54 \\
\hline & 2 & 5.04 & $1.00(0.00)$ & 53 \\
\hline & 3 & 5.11 & $1.05(0.05)$ & 55 \\
\hline & 4 & 5.23 & $1.02(0.06)$ & 53 \\
\hline & 5 & 5.21 & $1.03(0.05)$ & 54 \\
\hline & 6 & 5.17 & $1.01(0.05)$ & 56 \\
\hline & 7 & 5.25 & $1.11(0.04)$ & 54 \\
\hline & 8 & 5.20 & $1.08(0.04)$ & 57 \\
\hline \multirow{6}{*}{ Full scale } & 1 & 198.6 & 1.49 & 28 \\
\hline & 2 & 201.3 & 1.44 & 31 \\
\hline & 3 & 201.6 & 1.10 & 30 \\
\hline & 4 & 200.6 & 1.39 & 30 \\
\hline & 5 & 193.2 & 1.43 & 30 \\
\hline & 6 & 196.6 & 1.57 & 30 \\
\hline
\end{tabular}

\subsection{Data Analysis}

For the statistical significance of particle size in the evaluation of solid grinding efficiency, Mann-Whitney $U$-test or $t$-test was performed after the Shapiro-Wilk test for normality. A statistical software, SPSS 18.0 (IBM Corp., Armonk, New York, USA), was utilized. To determine the statistical significance with respect to the change in the removal rates of zooplankton during PT and FST, the coefficient of variation (CV) was calculated, and a $t$-test and one-way ANOVA analysis were performed.

\section{Results}

\subsection{Evaluation of Solid Grinding Efficiency}

The particle size distribution of all test dusts tended to be somewhat smaller after treatment compared to the distribution before treatment with the GD. A4 dust, which contains relatively larger particles, showed a large decrease in particle size (Figure 3). For the change in the average particle sizes for each dust, the average size of A2 dust before and after grinding decreased by approximately $3.8 \%$ from $8.42 \pm 9.56 \mu \mathrm{m}$ to $8.10 \pm 8.03 \mu \mathrm{m}$, and the average size of A4 dust before and after grinding decreased by approximately $18 \%$ from $19.1 \pm 22.6 \mu \mathrm{m}$ to $15.6 \pm 17.8 \mu \mathrm{m}$. In calculating the cumulative percentiles of $20 \%$ (D20), 50\% (D50), and 90\% (D90) of the total particle size to determine the degree of grinding effects in each dust, the particle grinding effect on A2 dust with relatively small particles was not identified up to D50, whereas the particle size at D90 decreased by $5.1 \mu \mathrm{m}$ after the grinding treatment (Table 4). In contrast, the particle size of A4 dust compared to A2 dust decreased at D50 by approximately $1.3 \mu \mathrm{m}$ after treatment, and the particle size at D90 decreased by approximately $7.3 \mu \mathrm{m}$, showing a more significant reduction in particle size compared to A2 dust. According to the results of statistical analysis, there was a statistically significant difference in both A2 dust at the particle size of $\geq 25 \mu \mathrm{m}$ and A4 dust at the particle size of $\geq 50 \mu \mathrm{m}$ (Table 5). 

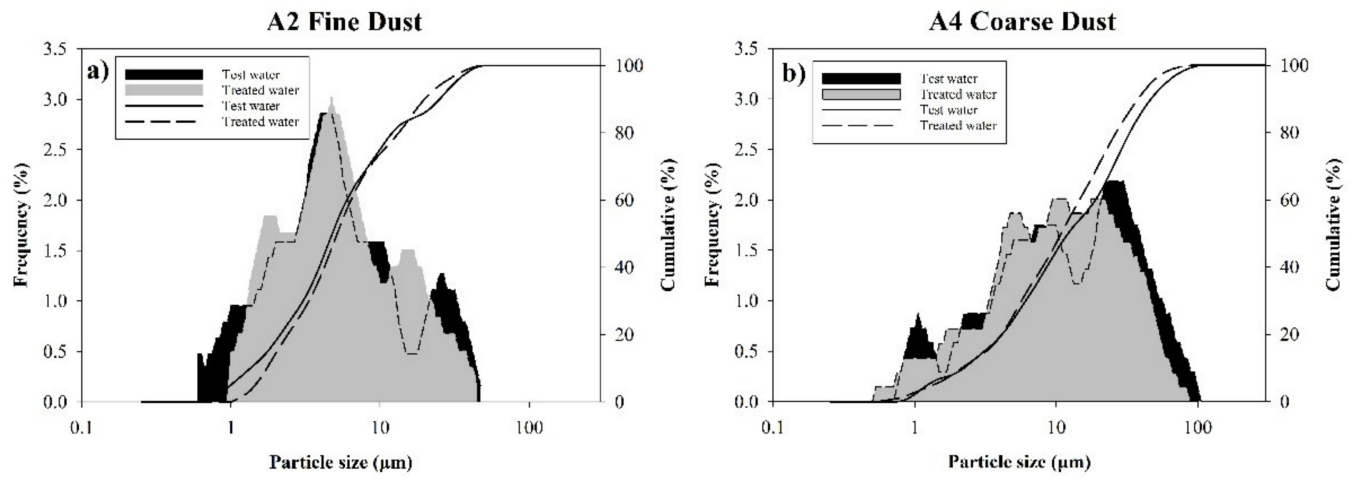

Figure 3. Particle distribution by size (\%) and particle size weighted distribution (\%) before/after Treatment; (a) A2 Fine Dust, (b) A4 Coarse Dust.

Table 4. Percentile changes of Inoculated dust particle size $(\mu \mathrm{m})$.

\begin{tabular}{ccccccc}
\hline \multirow{2}{*}{ Dust Type } & \multicolumn{2}{c}{ D20 } & \multicolumn{2}{c}{ D50 } & \multicolumn{2}{c}{ D90 } \\
\cline { 2 - 7 } & $*$ TW & ${ }^{*}$ Tr & TW & Tr & TW & Tr \\
\hline A2 & 2.18 & 2.44 & 4.87 & 5.16 & 25.1 & 20.0 \\
A4 & 4.10 & 4.40 & 12.2 & 10.9 & 46.0 & 38.7 \\
\hline
\end{tabular}

${ }^{*}$ TW (Test water), ${ }^{* *} \operatorname{Tr}$ (Treated water).

Table 5. Statistical analysis by dust particle size of Test water and Treated water (statistical significance level lower than $p<0.05^{\text {' }}+$ ' or $p<0.01$ is referred as ' ++ ').

\begin{tabular}{cccc}
\hline Dust Type & Experiment & Particle Size $(\mu \mathrm{m})$ & $p$-Value \\
\hline A2 fine dust & $\begin{array}{c}\text { Test water } \\
\text { Treated water } \\
\text { Test water } \\
\text { Treated water }\end{array}$ & $\geq 25-50^{* *}$ & 0.36 \\
\hline A4 coarse Dust & $\begin{array}{c}\text { Test water } \\
\text { Treated water } \\
\text { Test water } \\
\text { Treated water } \\
\text { Test water } \\
\text { Treated water }\end{array}$ & $\geq 25-50 *$ & 0.35 \\
\hline & $>50 *$ & 0.09 \\
\hline
\end{tabular}

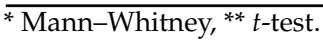

The TSS concentrations in the experimental water were $317 \pm 4.12 \mathrm{mg} \mathrm{L}^{-1}$ for A2 dust and $453 \pm 19.8 \mathrm{mg} \mathrm{L}^{-1}$ for A4 dust, and those in the treated water were $318 \pm 15.3 \mathrm{mg} \mathrm{L}^{-1}$ for A2 dust and $339 \pm 15.0 \mathrm{mg} \mathrm{L}^{-1}$ for A4 dust. The TSS results showed no change in TSS concentration in the case of A2 dust before and after treatment, whereas the TSS concentration in the case of A4 dust decreased by $100 \mathrm{mg} \mathrm{L}^{-1}$ or more.

\subsection{Evaluation of Removal Efficiency on $\geq 50 \mu m$ Zooplankton Species}

\subsubsection{Pilot Test}

A total of 8 phyla and 15 species of zooplankton with a size of $\geq 50 \mu \mathrm{m}$ were observed in the experimental water during a total of eight experiment sessions, and the IMO G8 Guidelines were met in all experiment sessions. Cirriped larvae had the highest contribution throughout the experiment at $22.1 \%$, followed by Copepodites $(15.8 \%)$, Copepoda nauplii (15.0\%), Paracalanus parvus (12.9\%), Harpacticoida (7.5\%), and Bivalvia larvae (7.1\%). The removal efficiency of the GD was determined to be $\geq 96 \%(98.5 \pm 0.83 \%, t$-test; $p<0.01)$ in the treated water of all PT sessions (Figure 4). According to the results of the experiment (sixth to eighth sessions), which checked the change in the mortality rate of the GD at $10 \mathrm{~min}$ intervals for approximately $50 \mathrm{~min}$ during the experiment, the mortality rate ranged 
from $98.2-99.1 \%$ in the sixth session, $98.1-99.6 \%$ in the seventh session, and $96.2-97.5 \%$ in the eighth session, respectively. The CV was less than $0.6 \%$, indicating that the performance of the GD was maintained at a constant level during the operating time. According to the results of the removal efficiency depending on the size of organisms in the eighth session among all experiments, the removal efficiency was $87 \%$ for the $50-70 \mu \mathrm{m}$ (based on the shorter side) zooplankton species, including Bivalve larvae and Copepoda nauplii, $94 \%$ for the $70-100 \mu \mathrm{m}$ zooplankton species, and $100 \%$ for the $>100 \mu \mathrm{m}$ zooplankton species (Table 6). According to the results of the death patterns before and after passing through the GD, most zooplankton died with their bodies cut after passing through the GD (Table 7). In particular, cut body or fallen appendages were clearly identified in copepods with a size $>100 \mu \mathrm{m}$. In the case of relatively small $(50-110 \mu \mathrm{m})$ copepods, such as Bivalvia larvae and Cirripedia larvae, numerous individuals with intact bodies were observed in the treated water.

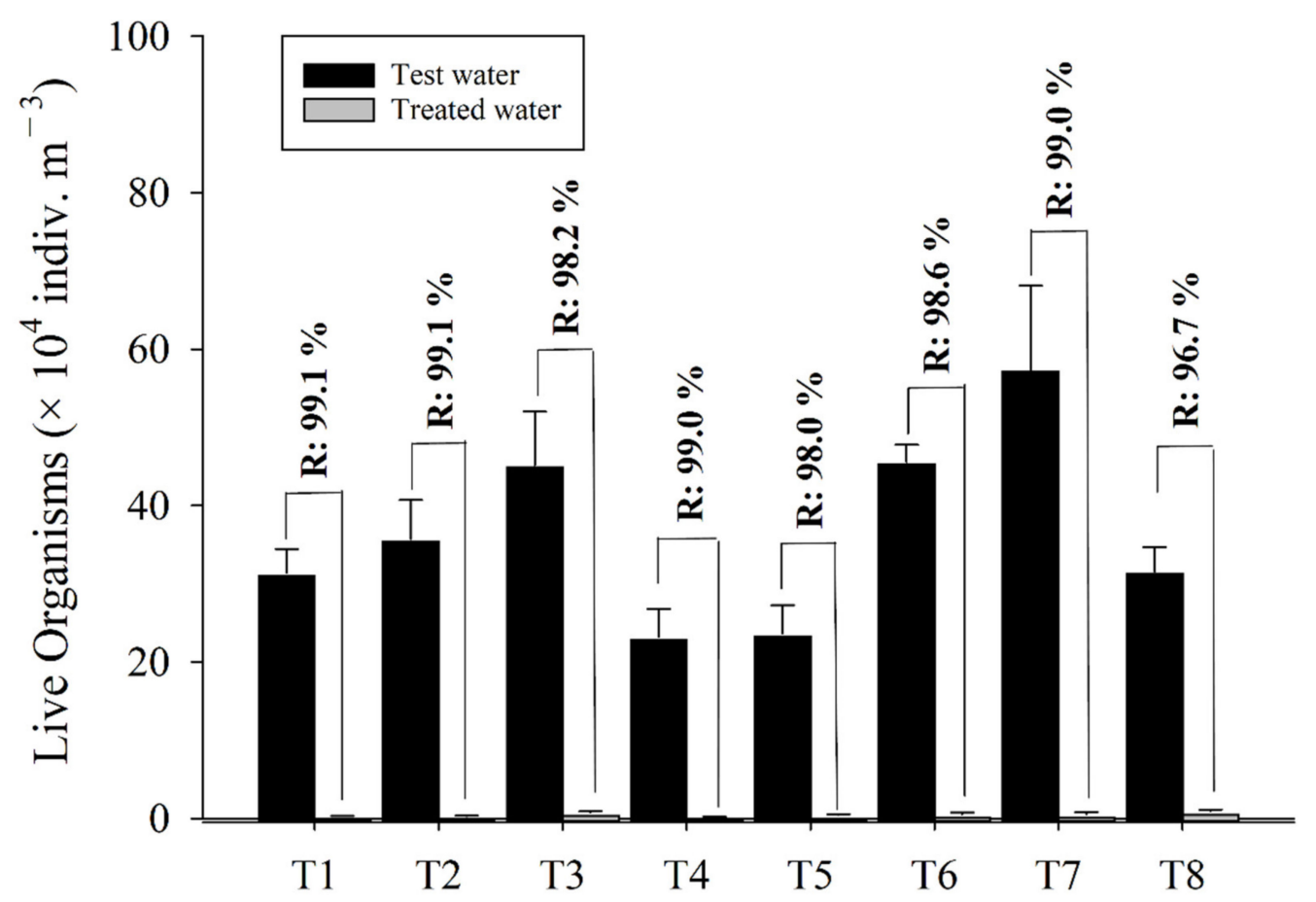

Figure 4. Removal efficiency of zooplankton species treated by GE BWMS pre-treatment system at each test cycle during pilot test period (R; removal efficiency).

Table 6. Removal efficiency of zooplankton species treated by GE BWMS pre-treatment system according to the size different in the 1-8th test cycle.

\begin{tabular}{cccc}
\hline Size $(\boldsymbol{\mu m})$ & Organisms & $\begin{array}{c}\text { Contribution Rate } \\
\mathbf{( \% )}\end{array}$ & $\begin{array}{c}\text { Removal Efficiency } \\
\mathbf{( \% )}\end{array}$ \\
\hline $50-70 \quad$ Copepoda nauplii, Bivalvia larvae & 22.1 & 87 \\
\hline \multirow{3}{*}{$\begin{array}{c}\text { Copepodites, Oithona spp., } \\
\text { Harpacticoida, Polychaeta larvae, } \\
\text { Cirripedia larvae, Gastropoda larvae, } \\
\text { Temora sylifera }\end{array}$} & 57 & 94 \\
\hline$>100 \quad$ Copepoda nauplii, Bivalvia larvae & 20.8 & 100 \\
\hline
\end{tabular}


Table 7. Photographs of major zooplankton species treated by GE BWMS pre-treatment system during pilot test period in the 8 th test cycle.

\begin{tabular}{|c|c|c|c|}
\hline Taxon & Before Treatment & After Treatment & Type \\
\hline Copepoda & & & Bodies cut \\
\hline Cirripedia larvae & & & \\
\hline Copepoda nauplii & & & Intact bodies \\
\hline Bivalvia larvae & & & \\
\hline
\end{tabular}

\subsubsection{Full-Scale Test}

A total of six FSTs were conducted on natural zooplankton communities in the seawater surrounding the barge. Although 8 phyla and 18 species were abundant during the experiment, the number of $\geq 50 \mu \mathrm{m}$ zooplankton species in the test water ranged from $17,200-77,800$ indiv. $\mathrm{m}^{-3}$, failing to meet IMO G8 Guidelines ( $>100,000$ indiv. $\mathrm{m}^{-3}$ ). Throughout all experiment sessions, Copepod nauplii had the highest contribution of $31.2 \%$, followed by Cirripedia larvae $(15.7 \%)$, Gastropoda larvae $(10.8 \%)$, Copepodites $(8.0 \%)$, and Rotifera $(7.9 \%)$. The removal efficiency of zooplankton was determined to be $>74 \%(81.1 \pm 7.67 \%, t$-test; $p<0.01)$ in the treated water of all experiment sessions, with the highest efficiency of $95 \%$ in the first session (Figure 5). According to the result of the additional mortality rate over time immediately after passing through the GD, there was no statistically significant difference within $2 \mathrm{~h}$ after passing through the GD (one-way ANOVA, $p=0.158$ ). In contrast, the removal efficiency in the treated water (sixth session) stored for 5 days was determined to be $99 \%$ (sixth session: initial removal rate $75.6 \%$ ), which indicates that no regrowth tendency of zooplankton was observed and that additional death proceeded (Figure 6). Regarding the removal efficiency of zooplankton by size, the 50-70 $\mu \mathrm{m}$ zooplankton groups with the smallest size showed an $85 \%$ mortality rate, and the 70-100 $\mu \mathrm{m}$ zooplankton groups with the next smallest size showed an $87 \%$ mortality rate. In the $>100 \mu \mathrm{m}$ zooplankton groups, including adult copepods, Noctiluca scintillans, and jellyfish larvae, a 100\% removal rate was observed, as in the PT (Table 8). Regarding the death pattern of zooplankton that passed through the GD, most adult zooplankton died with their bodies cut after passing through the GD (Table 7). In particular, cut body or fallen appendages were clearly identified in copepods with a size $>100 \mu \mathrm{m}$. However, numerous individuals of Bivalvia larvae, Copepoda nauplii, and Cirripedia larvae with intact bodies were observed. 


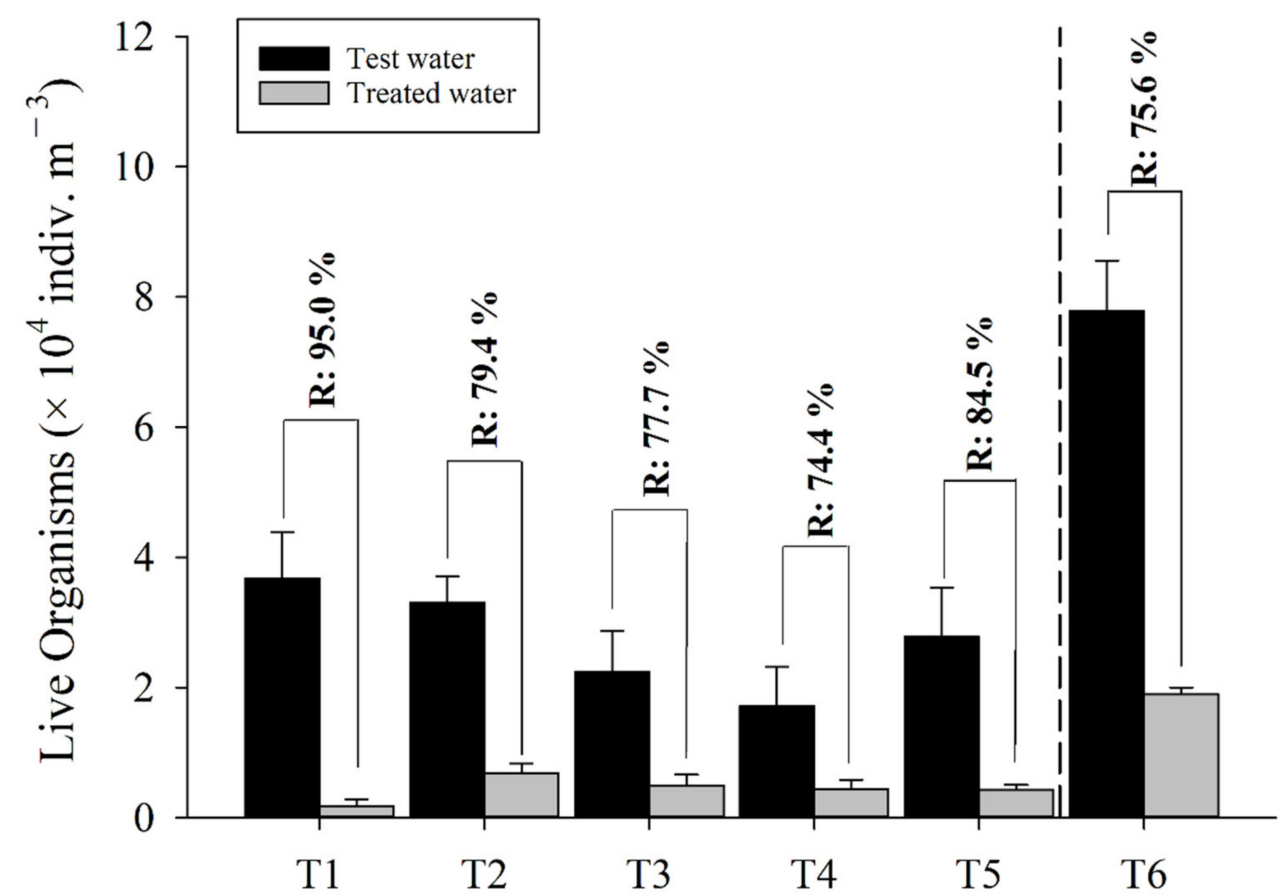

Figure 5. Removal efficiency of zooplankton species treated by GE BWMS pre-treatment system at each test cycle during full-scale test period ( $R$; removal efficiency).

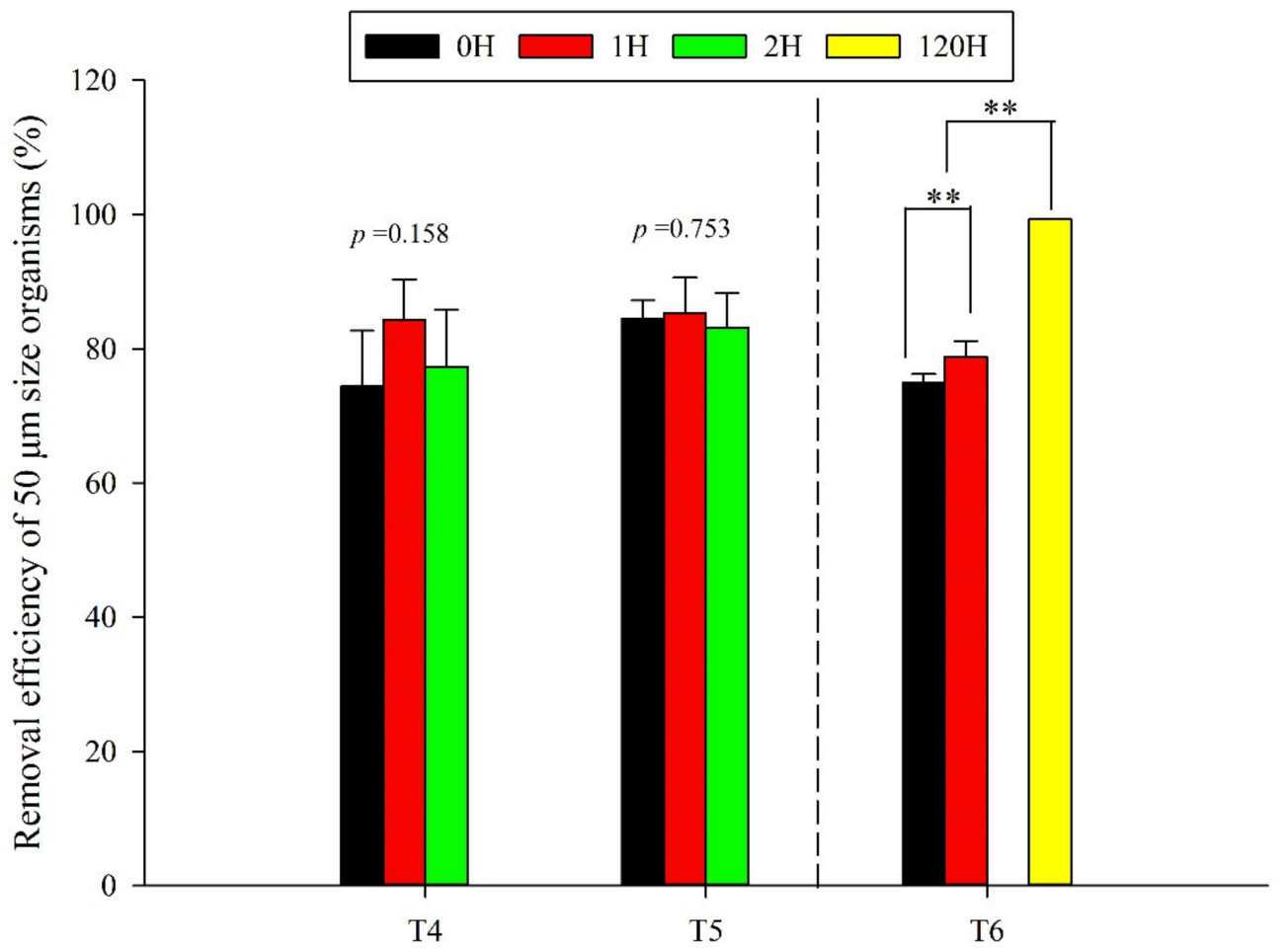

Figure 6. Statistical analysis by removal efficiency over time of zooplankton species (statistical significance levels lower than $p<0.05^{\text {*' }}$ or $p<0.01$ is referred as $\left.{ }^{* * \prime}\right)$. 
Table 8. Removal efficiency of zooplankton species treated by full-scale GE BWMS pre-treatment system according to the size different in the 1-5th test cycle.

\begin{tabular}{cccc}
\hline Size $(\boldsymbol{\mu m})$ & Organisms & $\begin{array}{c}\text { Contribution Rate } \\
(\mathbf{\%})\end{array}$ & $\begin{array}{c}\text { Removal Efficiency } \\
(\mathbf{\%})\end{array}$ \\
\hline $50-70$ & $\begin{array}{c}\text { Copepoda nauplii, Decapoda } \\
\text { larvae, Bivalvia larvae }\end{array}$ & 35.2 & 85 \\
\hline $70-100$ & $\begin{array}{c}\text { Polychaeta larvae, Copepodites, } \\
\text { Oithona spp., Rotifera, Gastropoda } \\
\text { larvae, Cirripedia larvae, Calanus } \\
\text { sinicus }\end{array}$ & 49.5 & \\
\hline \multirow{3}{*}{$\begin{array}{c}\text { Paracalanus aculeatus, Paracalanus } \\
\text { parvus, Eucalanus sp., Acartia } \\
\text { steueri, Acartia omorii, Oikopleura } \\
\text { spp., Monstrilloida, Evadne } \\
\text { tergestina }\end{array}$} & 10.4 \\
\hline
\end{tabular}

\section{Discussion}

As of 2019, approximately 70\% of all BWMSs installed on vessels utilize a filter unit as a pretreatment device to remove $\geq 50 \mu \mathrm{m}$ organisms, resulting in many difficulties in operation and management due to filter clogging caused by frequent stoppages in coastal areas with a high turbidity as well as adherence at idle. This study has identified the performance of the GD based on a flow-through method through solid grinding efficiency evaluation and evaluated the removal efficiency on zooplankton groups to improve the treatment efficiency of the main BWMS while overcoming the disadvantages of the conventional filtration devices. The results show that the GD effectively kills organisms (PT: approximately 94\%, FST: $81 \%$ ) and enables stable operation in a high-turbidity environment (Figure 7).

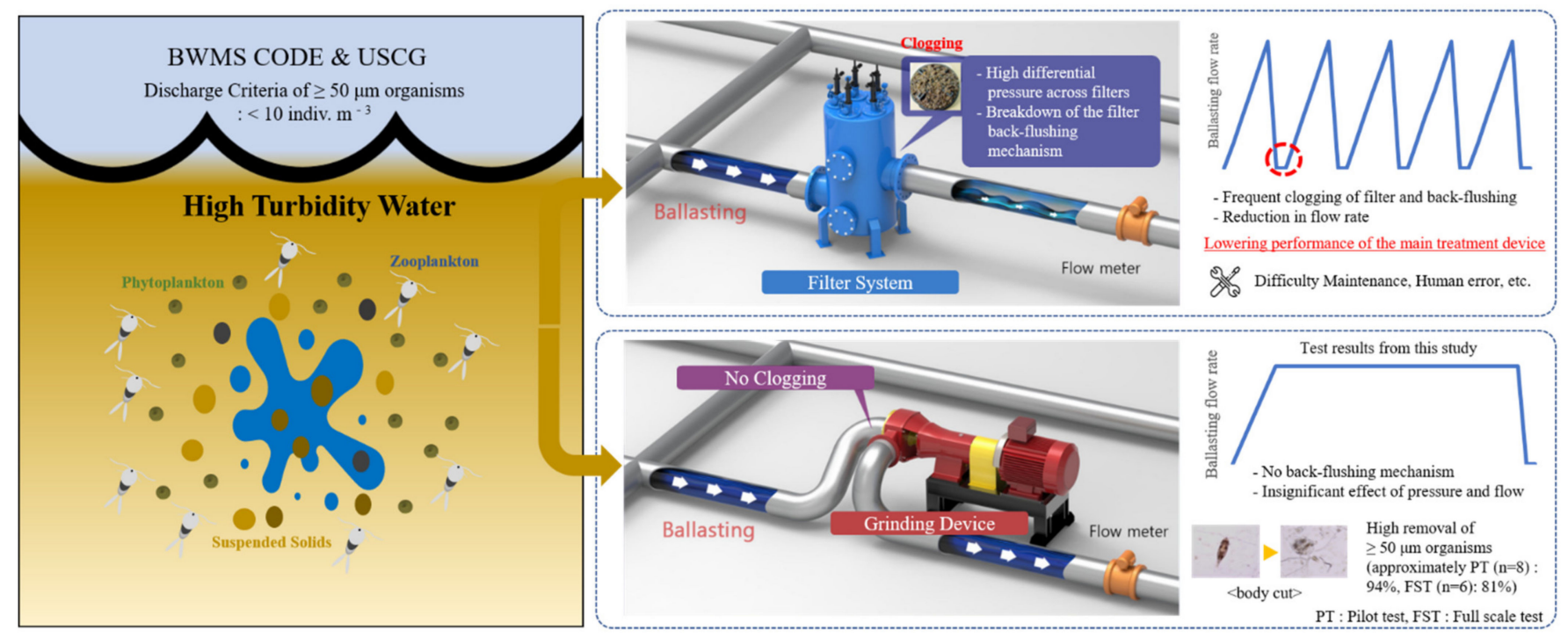

Figure 7. Summary of test results.

The GD is composed of a fixed unit and a drive unit that rotates at a high speed, and it applies the flow-through method, which is different from the filter method, a physical filtration method that filters marine organisms present in ballast water and uses elements, such as mesh or a screen. Thus, when the ballast water flows through the high-speed rotating GD, the water passes through the narrow gap between the driving part and the fixed part at an instantaneous speed of $50 \mathrm{~m} / \mathrm{s}$ or more, thereby decomposing and killing organisms within the ballast water due to impact, shear force, and cavitation up to 500 million times per s. "Impact" refers to the destruction of biological tissues due to 
collisions between particles or between particles and structures, and "shear force" refers to the destruction of biological tissues due to velocity difference and friction of fluids. Lastly, "cavitation" refers to a phenomenon in which biological tissue is destroyed due to the instantaneous pressure difference in ultra-high pressure or speed. Thus, because it is a grinding method rather than a filtration method using a filter, this study predicted that the flow rate reduction and system stoppage due to filter clogging by organisms would not occur. As a result, the stoppage phenomenon of the GD did not occur during the grinding evaluation experiments of solids (twice) and the viability experiments (PT 8 times, FST 6 times) in this study. Furthermore, we sampled water five times in the PT (6-8 times) at $10 \mathrm{~min}$ intervals to determine the removal efficiency of the GD according to the change in operating time. In this experiment, the $\mathrm{CV}$ value was determined as less than $0.6 \%$, showing that the constant performance of the GD was maintained regardless of operating time.

The results of the study show that the removal efficiency of the GD is affected by the size and shape of the organisms in the test water. In the PT experiment, in which zooplankton species (including Copepoda nauplii, Cirripedia larvae, Polychaeta larvae, Bivalvia larvae, and Gastropoda larvae) with a shorter side length of $<100 \mu \mathrm{m}$ occupied approximately half $(50.2 \%)$ of those found, the removal efficiency was approximately $94 \%$. By contrast, the removal efficiency in the FST experiment, where small zooplankton species occupied approximately $95.2 \%$, was approximately $74 \%$. The size group involving many Copepoda nauplii and Cirripedia larvae $(100-50 \mu \mathrm{m})$ showed low removal efficiency compared to the size group $(>100 \mu \mathrm{m})$ involving a great number of relatively large adult copepods (Tables 6 and 8). This result shows that the size distribution of the organisms in the test water flowing into the GD affects the performance of the GD. Furthermore, differences between GDs in performance due to morphological characteristics were also identified. In the PT experiment, Copepodites and Polychaeta larvae, which belong to the same size group and have a relatively higher length of the longer side, showed a mortality rate of $97.9 \%$ and $97.5 \%$, respectively. These species showed higher mortality rates than those of Cirripedia larvae (mortality rate: $89.5 \%$ ) and Gastropodia larvae (mortality rate: $80.5 \%$ ), which have semi-circled or equilateral triangle shapes rather than elongated ones. This trend was also observed in the FST experiment (species name/mortality rate: Copepodites/92.3, Polychaeta larvae/ 94.3, Cirripedia larvae/54.0, Gastropodia larvae/85.3). The body size and species composition in the influent have also been reported to affect the filtration device, which is currently mostly used as a pretreatment device for the BWMS. Briski et al. [12] conducted a performance evaluation of the same filtration device (40 $\mu \mathrm{m}$ stainless steel candle filter) in three Canadian sea areas (Quebec City, Sarnia, and Thunder Bay). The results showed that the removal efficiency varied from $17 \%$ to $73 \%$ depending on the species composition of the zooplankton in the sea areas subjected to experiments. Another study by Wright et al. [22] that utilized the filtration system with a mesh size of $55 \mu \mathrm{m}$ to confirm the removal efficiency of organisms $(\geq 50 \mu \mathrm{m})$ reported that the removal efficiency ranged from 53.4-95.1\% depending on the species composition in the influent. Briski et al. [12] also reported on the effects of the morphological characteristics of organisms in the influent on the performance of the filtration device. In Quebec City (removal efficiency: $17 \%$ ), which showed the lowest removal efficiency, the standing crop of the small zooplanktons, such as Juvenile dreissenid veliger larvae and Rotifers, which have soft bodies, was high. These species could pass through filters smaller than their own body size due to their morphological characteristics. Conversely, the same study reported that there was relatively high removal efficiency because adults of the Copepods (including Leptodiaptomus minutus, Skistodiaptomus pallidus, and Hemidiaptomus sp.), which were not observed in the influent during the shipboard test performed in Quebec City, were abundant in Sarnia, which had the highest removal efficiency, whereas the smaller rotifers species was not abundant.

The additional removal effect of the GD on $\geq 50 \mu \mathrm{m}$ organisms was also identified. Because the small zooplankton group with a size of $<100 \mu \mathrm{m}$, which had low removal 
efficiency of the GD in this study, contained numerous species with a coin-shaped flat or flexible body, it was relatively less crushed and ground by the GD. Thus, although the mortality rate immediately after treatment was lower than that of adult copepods composed of chitin, the results show that most of the organisms that survived immediately after treatment died ( $\geq 99 \%$ ) within 5 days due to the physical damage they received while passing through the GD. A study by Stehouwer et al. [23] regarding the performance evaluation of the BWMS adopting the UV method reported that it is difficult to confirm the maximum removal effect within 1 day even when the UV intensity is high and that it is thus necessary to check the additional death of organisms for up to 5 days when the UV intensity is low. Briski et al. [12] also reported on the possibility that additional death of organisms passing through the filter may occur. Although this study was able to identify an additional high removal effect for $\geq 50 \mu \mathrm{m}$ organisms that passed through the GD, the corresponding experiment was performed only once, and the three-set analysis (immediately after treatment, $1 \mathrm{~h}$ after treatment, and $12 \mathrm{~h}$ after treatment) was insufficient in determining the mortality rate between $1 \mathrm{~h}$ and $120 \mathrm{~h}$. Considering these limitations, further verification experiments are necessary.

The grinding effect on the solids in the test water was also examined through the change in the particle sizes and TSS concentrations before and after the treatment of the solids. The TSS concentrations in the influent before passing through the GD were $317 \mathrm{mg} \mathrm{L}^{-1}$ (A2) and $453 \mathrm{mg} \mathrm{L}^{-1}$ (A4), which were on the level similar to the concentration of suspended solids in the Port of Shanghai, China $\left(690 \mathrm{mg} \mathrm{L}^{-1}, 310 \mathrm{mg} \mathrm{L}^{-1}\right.$, and $351 \mathrm{mg} \mathrm{L}^{-1}$ ) reported by Jang et al. [11], whereas these TSS concentrations were higher than those in the Port of Shaman $\left(93.3 \mathrm{mg} \mathrm{L}^{-1}\right)$, the Port of Ningbo $\left(82.0 \mathrm{mg} \mathrm{L}^{-1}\right)$, and other ports in China, as well as those in the Port of Singapore $\left(22.0 \mathrm{mg} \mathrm{L}^{-1}, 22.4 \mathrm{mg} \mathrm{L}^{-1}\right)$ and the Port of Hong Kong (22.8 mg L $\left.\mathrm{mg}^{-1}, 29.4 \mathrm{mg} \mathrm{L}^{-1}\right)$ in Southeast Asia. Jang et al. (2020) reported that the high concentration of suspended solids in Shanghai and Shaman clogged the filter, lowered the performance of the main treatment device, and interrupted the BWMS management, thereby preventing the normal progression of tests. However, the GD effectively reduced the average particle size of the injected solids in the PT in a high-turbidity condition that was conducted twice and further prevented stoppage of the GD and increases in the pressure between the pump and the GD. This change in the particle sizes of solids in treated water could also be identified by the cumulative percentile result of particle size and the TSS concentration change. In the A4 dust experiment containing numerous large particles, the TSS concentration was reduced from $453 \pm 19.8 \mathrm{mg} \mathrm{L}^{-1}$ (test water) to $339 \pm 15.0 \mathrm{mg} \mathrm{L}^{-1}$ (treated water), and D90, which was the cumulative percentile of particle size, decreased from an average of $46.0 \mu \mathrm{m}$ to an average of $38.7 \mu \mathrm{m}$. This result shows that the large-sized solids were ground by the GD and converted into smaller particles.

To improve the processing efficiency of the BWMS and secure stable operation performance in a high-turbidity environment, this study investigated the performance of a new-type GD that can replace the conventional filtration device. To utilize the GD as a pretreatment device for the BWMS, suspended solids (living matter) must be removed at a high yield, and the impact of performance degradation due to the introduced suspended solids must be low. The results of this study show that the GD is affected by the size and shape of the inflowing species similar to the filtration device used for the same purpose. However, despite the experimental water conditions, in which small zooplanktons with a size of $<100 \mu \mathrm{m}$ were dominant, the initial removal efficiency after treatment was as high as $\geq 87 \%$ (average value of PT and FST results), and most $\geq 50 \mu \mathrm{m}$ organisms ( $\geq 99 \%$ ) were died by the additional physical effects within 5 days. Moreover, this new device can secure stable operation performance even in environments with high turbidity and high biological concentration. From these results, this GD could be utilized as a pretreatment device for the BWMS and sufficiently replace the filtration device.

Author Contributions: B.H. system set-up, sampling, writing-original draft; H.-G.C. and Y.-K.A. sampling, analyzed the data; Y.-S.P. GD system development, set-up and operation; M.-C.J. and P.-G.J. 
revised draft; K.S. supervision, conceptualization, funding acquisition. All authors have read and agreed to the published version of the manuscript.

Funding: This research was supported by the research and development program (20180035, 20180221) funded by the Ministry Oceans and Fisheries, Korea.

Institutional Review Board Statement: Not applicable.

Informed Consent Statement: Not applicable.

Data Availability Statement: All data used to support the findings of this study are included within the article.

Acknowledgments: The authors would like to thank the Ballast Water Research Center members in KIOST for their help with sampling and analysis.

Conflicts of Interest: The authors declare no conflict of interest. The funders had no role in the design of the study; in the collection, analyses, or interpretation of data; in the writing of the manuscript; or in the decision to publish the results.

\section{References}

1. Roy, S.; Parenteau, M.; Casas-Monroy, O.; Rochon, A. Coastal Ship Traffic: A Significant Introduction Vector for Potentially Harmful Dinoflagellates in Eastern Canada. Can. J. Fish. Aquat. Sci. 2012, 69, 627-644. [CrossRef]

2. Hyun, B.; Baek, S.H.; Shin, K.; Choi, K.-H. Assessment of Phytoplankton Invasion Risks in the Ballast Water of International Ships in Different Growth Conditions. Aquat. Ecosyst. Health Manag. 2017, 20, 423-434. [CrossRef]

3. Endresen, Ø.; Behrens, H.L.; Brynestad, S.; Andersen, A.B.; Skjong, R. Challenges in Global Ballast Water Management. Mar. Pollut. Bull. 2004, 48, 615-623. [CrossRef] [PubMed]

4. Cha, H.-G.; Seo, M.-H.; Lee, H.-Y.; Lee, J.-H.; Lee, D.-S.; Shin, K.; Choi, K.-H. Enhancing the Efficacy of Electrolytic Chlorination for Ballast Water Treatment by Adding Carbon Dioxide. Mar. Pollut. Bull. 2015, 95, 315-323. [CrossRef] [PubMed]

5. Kang, J.-H.; Hyun, B.-G.; Shin, K. Phytoplankton Viability in Ballast Water from International Commercial Ships Berthed at Ports in Korea. Mar. Pollut. Bull. 2010, 60, 230-237. [CrossRef] [PubMed]

6. Takahashi, C.; Lourenço, N.; Lopes, T.; Rall, V.L.M.; Lopes, C. Ballast water: A Review of the Impact on the World Public Health. J. Venom. Anim. Toxins Incl. Trop. Dis. 2008, 14, 393-408. [CrossRef]

7. Padilla, D.K.; Williams, S.L. Beyond Ballast Water: Aquarium and Ornamental Trades as Sources of Invasive Species in Aquatic Eco-Systems. Front. Ecol Env. 2004, 2, 131-138. [CrossRef]

8. International Maritime Organization. International Convention for the Control and Management of Ship's Ballast Water and Sediments(BWM).aspx. 2004. Available online: http://www.imo.org/en/About/Conventions/ListOfConventions/Pages/InternationalConvention-for-the-Control-and-Management-of-Ships\%27-Ballast-Water-and-Sediments- (accessed on 8 August 2020).

9. IMO. Ballast Water Management Under the Ballast Water Management Convention. In Global Maritime Transport and Ballast Water Management; David, M., Gollasch, S., Eds.; Springer: Dordrecht, Neatherlands, 2015; Volume 8.

10. International Maritime Organization. Guidance on Ballast Water Sampling and Analysis for Trial Use in Accordance with BWM Convention and Guidelines (G2). (BWM.2/Circ.42). 2013. Available online: https://docs.imo.org/Search.aspx?keywords=BWM. 2\%2FCirc.42 (accessed on 8 August 2020).

11. Jang, P.-G.; Hyun, B.; Shin, K. Ballast Water Treatment Performance Evaluation under Real Changing Conditions. J. Mar. Sci. Eng. 2020, 8, 817. [CrossRef]

12. Briski, E.; Linley, R.D.; Adams, J.; Bailey, S. Evaluating Efficacy of a Ballast Water Filtration System for Reducing Spread of Aquatic Species in Freshwater Ecosystems. Manag. Biol. Invasions 2014, 5, 245-253. [CrossRef]

13. American Bureau of Shipping (ABS). 2019 Best Practices for Operations of Ballast Water Management Systems Report. Available online: https:/ /ww2.eagle.org/en/Products-and-Services/environmental-performance/ballast-water-management/bestpractices-bwm-report.html (accessed on 8 August 2020).

14. Tsolaki, E.; Diamadopoulos, E. Technologies for Ballast Water Treatment: A Review. J. Chem. Technol. Biotechnol. 2010, 85, 19-32. [CrossRef]

15. Riley, S.C.; Lemieux, E.J.; Robbins, S.H. Testing of Filter Technologies for Ballast Water Treatment. IEEE 2006, 3, 2511-2518. [CrossRef]

16. Ramchander, K.; Hegde, M.; Antony, A.P.; Wang, L.; Leith, K.; Smith, A.; Karnik, R. Engineering and Characterization of Gymnosperm Sapwood toward Enabling the Design of Water Filtration Devices. Nat. Commun. 2021, 12, 1-17. [CrossRef] [PubMed]

17. APHA, APHA, AWWA and WEF. Standard Methods for the Examination of Water and Wastewater, 22nd ed.; American Public Health Association: Washington, DC, USA, 2012.

18. Salim, R.; Cooksey, B. The Effect of Centrifugation on the Suspended Particles of River Waters. Water Res. 1981, 15, 835-839. [CrossRef] 
19. Marine Environmental Protection Committee. Guidelines for Approval of Ballast Water Management Systems(G8) (MEPC58/23). 2008. Available online: https:/ / docs.imo.org/Category.aspx?cid=47\&session=58 (accessed on 8 August 2020).

20. Fleming, J.M.; Coughlan, J. Preservation of Vitally Stained Zooplankton for Live/Dead Sorting. Estuaries 1978, 1, $135-137$. [CrossRef]

21. NSF International. Generic Protocol for the Verification of Ballast Water Treatment Technology. US EPA, Washington, DC, EPA/600/R-10/146. 2010. Available online: https:// cfpub.epa.gov/si/si_public_record_Report.cfm?Lab=NRMRL\&dirEntryId= 230926\&CFID=25387471\&CFTOKEN=82327913\&jsessionid=3830878cac2eed65ab65527d6e7047c54330 (accessed on 21 July 2021).

22. Wright, D.A.; Dawson, R.; Orano-Dawson, C.E.; Moesel, S.M. A Test of the Efficacy of a Ballast Water Treatment System Aboard the Vessel Coral Princess. Mar. Technol. SNAME News 2007, 44, 57-67. [CrossRef]

23. Stehouwer, P.P.; Fuhr, F.; Veldhuis, M. A novel Approach to Determine Ballast Water Vitality and Viability after Treatment, Emerging Ballast Water Management Systems. Proceedings of the IMO-WMU Research and Development Forum 2010, malmö, Sweden, 233-240. Available online: https://www.researchgate.net/profile/Newton-Pereira/publication/259148856_A_STUDY_ OF_BALLAST_WATER_TREATMENT_APPLIED_ON_IRON_ORE_PORTS_IN_BRAZIL_USING_DISCRETE_SIMULATION/ links / 02e7e5275d2606f5f8000000 / A-STUDY-OF-BALLAST-WATER-TREATMENT-APPLIED-ON-IRON-ORE-PORTS-INBRAZIL-USING-DISCRETE-SIMULATION.pdf\#page=248 (accessed on 21 July 2021). 